\title{
A INAPLICABILIDADE DO MARCO TEMPORAL QUILOMBOLA E AS RETOMADAS DE TERRAS SOB A PERSPECTIVA DO DIREITO COMO EFETIVIDADE
}

\author{
Carlos Eduardo Lemos Chaves* \\ Aianny Naiara Gomes Monteiro** \\ José do Carmo Alves Siqueira***
}

\section{RESUMO}

O trabalho analisa os efeitos sobre as retomadas de terras por quilombolas, a partir da decisão do Supremo Tribunal Federal (STF), que julgou improcedente a Ação Direta de Inconstitucionalidade (ADI) 3239, reconhecendo constitucional o Decreto $n^{\circ} 4.887 / 2003$ e inaplicável a tese do marco temporal às titulações dos territórios quilombolas. Pela análise dos votos proferidos no julgamento e uma revisão bibliográfica, conclui-se que a decisão reconhece as ações de retomada e, com base na tese do Direito como efetividade, abre perspectiva para reocupações em defesa da posse tradicional enquanto ferramenta para o avanço rumo à efetividade do seu direito à titulação.

Palavras-chave: Direito Agrário; quilombos; ADI n 3239; retomadas de terras; Direito como efetividade.

\section{THE INAPPLICABILITY OF THE QUILOMBOLA TEMPORAL FRAMEWORK AND THE LAND RETAKINGS FROM THE PERSPECTIVE OF LAW AS EFFECTIVENESS}

\begin{abstract}
The article analyzes the effects on the land retakings by quilombolas, based on the Supreme Court of Brazil decision, which dismissed the Direct Action of Unconstitutionality (DAU) 3239, recognizing the Decree $\mathrm{n}^{\mathbf{0}} 4887 / 2003$ as constitutional and the thesis of the temporal framework inapplicable to the quilombola territories titlings. By analyzing the votes in the trial and bibliographic review, it concludes that the decision recognizes the retakings actions and, based on the thesis of Law as effectiveness, opens perspective for reoccupations in defense of traditional possession as instrument for advancing towards the effectiveness of their titling right.
\end{abstract}

Keywords: Agrarian Law, quilombos, DAU nº 3239, land retakings, Law as effectiveness.

\section{Introdução}

\footnotetext{
* Mestrando no Programa de Pós-Graduação em Direito Agrário da Universidade Federal de Goiás - UFG (Bolsista CAPES). Especialista em Direitos Sociais do Campo pela Residência Agrária da UFG (Bolsista CNPq). Advogado associado à Associação de Advogados(as) de Trabalhadores(as) Rurais no Estado da Bahia - AATR. E-mail: celchaves@gmail.com.

** Doutoranda no Programa de Pós-Graduação em Direito da Universidade Federal do Pará - UFPA. Mestra em Agricultura Familiar e Desenvolvimento Sustentável pelo Programa de Pós-Graduação em Agriculturas Amazônicas da UFPA. Advogada. E-mail: aiannymonteiro@yahoo.com.br.

*** Doutor em Direito pela Universidade de Brasília - UnB. Mestre em Direito pela Universidade Federal de Goiás - UFG. Professor Adjunto do Curso de Direito da UFG - Regional Goiás e do Programa de Pós-Graduação em Direito Agrário da UFG - Regional Goiânia. Advogado. E-mail: josedocarmoas@ gmail.com.
} 


\section{A INAPLICABILIDADE DO MARCO TEMPORAL QUILOMBOLA E AS RETOMADAS DE TERRAS SOB A PERSPECTIVA DO DIREITO COMO

A tese do marco temporal ganhou repercussão, em março de 2009, com o histórico julgamento, pelo Supremo Tribunal Federal (STF), do caso da Terra Indígena (TI) Raposa/Serra do Sol (BRASIL, 2009). Embora de aplicação ainda controversa, no âmbito do próprio STF, decisões da sua Segunda Turma, nos casos da TI Guyraroká, do Povo Guarani e Guarani Kaiowá (BRASIL, 2014a) e da TI Limão Verde, do Povo Terena (BRASIL, 2014b), reinterpretaram seu conteúdo para anular atos administrativos que delimitaram terras indígenas já demarcadas.

Estas controversas decisões do STF criaram um ambiente de insegurança jurídica em que, além de inspirar a expedição de atos do executivo ${ }^{1}$ e proposições de projetos de leis ${ }^{2}$, reinterpretando a aplicação dos direitos territoriais indígenas e quilombolas, também serviram como argumento, nas instâncias inferiores do Judiciário, para descaracterizar ocupações centenárias e impedir que tais comunidades recuperem a integralidade dos seus territórios por meio da retomada ou reocupação de suas terras tradicionais (CHAVES; CORREIA, 2018).

A tese do marco temporal surge, no Judiciário, como estratégia para frear as ações de retomada, enquanto forma legítima adotada pelas comunidades para fazer frente à intencional paralisação das políticas de demarcação e de titulação, buscando dar efetividade aos direitos territoriais inerentes à sua própria sobrevivência ou, ainda, organizar resistência face a uma agenda estatal submissa ao interesse de setores da economia em abrir, para o mercado de terras ou para o setor minerário nos subsolos, os territórios de uso comum.

Neste sentido, o artigo tem por objetivo demonstrar o impacto do julgamento da Ação Direta de Inconstitucionalidade (ADI) 3239/2004 sobre as ações de retomada, com a superação do entendimento firmado pela Segunda Turma do STF, ao decidir pela constitucionalidade do Decreto $n^{\circ} 4.887 / 2003$ e pela não aplicação da tese do marco temporal aos procedimentos de titulação dos territórios quilombolas. Para tanto, metodologicamente, é adotada a revisão bibliográfica acerca do fenômeno das retomadas e do marco temporal quilombola e da análise documental em processos judiciais, sobretudo quanto aos votos proferidos pelos(as)

\footnotetext{
${ }^{1}$ O Parecer no 001/2017 da Advocacia Geral União, que impõe a aplicação da tese do marco temporal e das 19 condicionantes do julgamento da TI Raposa/Serra do Sol em todos os processos de demarcação de terras indígenas, teve recentemente seus efeitos suspensos por decisão do Ministro Edson Fachin do STF, em relação à TI Ibirama La-Klãnô, do povo indígena Xokleng (Santa Catarina).

2 A Proposta de Emenda à Constituição (PEC) 215/2000 propõe modificar a Constituição para transferir ao Congresso Nacional a competência para a aprovação ou a ratificação das demarcações de terras indígenas, titulações dos territórios quilombolas e a criação de unidades de conservação para proteção do meio ambiente.
} 
Ministros(as) do STF na ADI 3239/2004, à luz da tese do Direito como efetividade (SIQUEIRA, 2016).

O julgamento firmou precedente fundamental para o enfrentamento às inciativas do governo do presidente Jair Bolsonaro, cuja eleição foi fundamentada em discurso racista e de apologia à violência contra os povos do campo, e vem reafirmando, na prática do exercício da presidência da República, a polêmica promessa de campanha de que não haveria mais nenhum centímetro de terra reconhecido para povos indígenas ou quilombolas com a sua eleição, postura que evidencia uma violação a compromissos firmados na Constituição.

Em seu primeiro ato no governo, a Medida Provisória (MP) $n^{\circ} 870$, de $1^{\circ}$ de janeiro de 2019, Jair Bolsonaro, sem consulta prévia às comunidades, extinguiu a Secretaria Especial de Agricultura Familiar e do Desenvolvimento Agrário, vinculou o Instituto Nacional de Colonização e Reforma Agrária (Incra) e repassou a prerrogativa da Fundação Nacional do Índio (Funai) de identificar e demarcar terras indígenas ao Ministério da Agricultura, Agropecuária e Abastecimento (MAPA), hegemonizado pelo setor ruralista, franco opositor das políticas territoriais quilombola e indigenista. Em seguida, vetou a dotação de 50 milhões de reais destinados à reestruturação de cargos e carreiras no Incra, entidade responsável pelo processo de titulação dos territórios quilombolas, e contingenciou em $90 \%$ o orçamento da Funai previsto na Lei Orçamentária Anual.

Desde então, têm sido constantes as ações oficiais dirigidas a retrocessos nos direitos conquistados por esses povos e populações, mediante propostas legislativas, nomeação de quadros com interesses contrários às demarcações e titulações, e até interferências direitas nos procedimentos administrativos que deveriam efetivar os direitos constitucionais de indígenas e quilombolas. Contexto que atrai a reflexão para as ações das comunidades quilombolas que visam seu retorno às porções de seus territórios ilegalmente ocupados por terceiros, à luz dos termos do julgamento da ADI 3239/2004, que rejeitou a tese do marco temporal quilombola.

\section{A "tese" do marco temporal como fundamento de ações possessórias e de criminalização das ações de retomada de terras-territórios}

Assim como as ocupações de terras para os movimentos de luta pela reforma agrária, as retomadas de terras têm sido o principal instrumento político de povos originários e comunidades tradicionais, não só para reaver porções usurpadas de seus territórios, mas para pressionar o Estado brasileiro a efetivar o direito à sua demarcação, titulação ou à cessão do seu uso.

Rev. de Direito Agrário e Agroambiental | e-ISSN: 2526-0081| Evento Virtual| v. 6 | n. 1 | p. 57-77 | Jan/Jun. 2020 


\section{A INAPLICABILIDADE DO MARCO TEMPORAL QUILOMBOLA E AS RETOMADAS DE TERRAS SOB A PERSPECTIVA DO DIREITO COMO \\ EFETIVIDADE}

A despeito da anterior lentidão e da atual omissão administrativa quanto às demarcações e às titulações, a incorporação ao ordenamento de normas garantidoras de direitos dos povos e comunidades tradicionais a partir da promulgação da Constituição de 1988, que inclui a edição do próprio Decreto $\mathrm{n}^{\circ}$ 4.887/2003, levou as comunidades a reivindicarem, com grande força, ao Estado a certificação da sua autoatribuição identitária e os direitos territoriais correlatos. Mas a opção política dos sucessivos governos por não demarcar os territórios vem conduzindo às retomadas das áreas invadidas por terceiros ao longo dos séculos de violações de direitos e de invisibilidade política/jurídica das comunidades.

Embora seja conceito de maior evidência na luta política dos povos indígenas, descritas na antropologia enquanto "processos por meio dos quais coletividades indígenas recuperam áreas tradicionalmente ocupadas que se encontravam em posse de não indígenas" (ALARCON, 2019, p. 19), as retomadas de terras por comunidades quilombolas vêm despontando, com certa frequência, nos processos administrativos e judiciais que discutem a propriedade e a posse de seus territórios tradicionais. Em ambos os casos, as retomadas de terras são vistas como grande ameaça pelos setores interessados na manutenção do latifúndio e consequente exploração das riquezas naturais existentes nessas áreas.

Como obstáculo à efetivação do direito quilombola sobre suas terras, recordam Monteiro e Treccani (2019, p. 23): “já existia formalmente a previsão de um marco temporal da ocupação quilombola preceituada no Decreto $n^{\circ} 3.912 / 2001$, expressamente revogado pelo Decreto n ${ }^{\circ} 4.887 / 2003$ ". Na primeira regulamentação da matéria, pelo Decreto no 3.912/2001, eram consideradas partes do seu território apenas as áreas ocupadas pelas comunidades quilombolas no período compreendido entre 1888 e 1988, ou seja, desde a assinatura da Lei Áurea até a promulgação da atual Constituição, conforme os incisos I e II, do parágrafo único, do art. $1^{\circ}$, do decreto revogado ${ }^{3}$ (MONTEIRO; TRECCANI, 2019).

Não surpreende, portanto, que, ao propor a ADI 3239/2004, poucos meses após a edição do Decreto n ${ }^{\circ} 4.887 / 2003$, o então Partido da Frente Liberal (PFL), que, desde 2007, passou a adotar o nome Democratas ${ }^{4}$, defendia que nas titulações dos quilombos a "área cuja a [sic]

\footnotetext{
3 “Art. 1으...)

Parágrafo único. Para efeito do disposto no caput, somente pode ser reconhecida a propriedade sobre terras que: I - eram ocupadas por quilombos em 1888; e

II - estavam ocupadas por remanescentes das comunidades dos quilombos em 5 de outubro de 1988" (BRASIL, 2001).

${ }^{4}$ Ver Estatuto do Partido Político Democratas, "novo nome do Partido da Frente Liberal, por deliberação de sua Convenção Nacional Extraordinária de Refundação", realizada em 28/03/2007, cujo Estatuto foi aprovado em 12/60/2007, nos termos da Resolução do Tribunal Superior Eleitoral - TSE n⿳0 22.550, DJ de 26/06/2007.
} 
propriedade deve ser reconhecida constitui apenas e tão-somente o território em que comprovadamente, durante a fase imperial da história do Brasil, os quilombos se formara [sic]" (BRASIL, 2018, p. 12) .

Solazzi e Wolkmer (2016, p. 37) apontam ainda que "não é de se estranhar a não inclusão do Decreto no 3912/2001 na ADI 3239/2004, dada a sua intenção de colocar fim imediato a qualquer demanda de reconhecimento étnico afro-brasileiro emergente", embora se pleiteasse a inconstitucionalidade formal do decreto atual sob o argumento de que a matéria nele contida teria invadido esfera reservada à lei, sendo o apontado vício também atribuível ao decreto anterior.

Por óbvio, reavivar juridicamente, por meio da ADI 3239/2004, o não reconhecimento a qualquer ocupação não contínua entre os anos de 1888 e 1988, ou não efetiva em 5 de outubro de 1988, seria alternativa, caso não declarada a inconstitucionalidade total do Decreto $\mathrm{n}^{\circ}$ 4.887/2003, para impedir que comunidades quilombolas reclamassem, ou retomassem, as porções do seu território que lhes foram retiradas em momento anterior à nova ordem constitucional, tipificando tais ações, como ainda costuma acontecer, na área penal como crime de esbulho possessório e/ou assim tratada para efeitos de ação possessória na área cível.

O Quilombo de Barra do Parateca, cuja origem remonta à escravidão nas antigas fazendas de gado e de algodão da região oeste da Bahia, foi reconhecido e certificado pela Fundação Cultural Palmares, no ano de 2004. Localizado no Município de Carinhanha (BA), suas ações de retomada consistiram na reocupação dos lameiros $^{6}$ das margens do Rio São Francisco, áreas da União, registradas e cercadas ilegalmente por pretensos/as proprietários/as (BAHIA, 2015).

A movimentação política em prol da efetivação de seus direitos territoriais, embora tenha resultado no avanço do procedimento administrativo de titulação pelo Incra, rendeu à comunidade mais de 10 ações judiciais possessórias e queixas criminais, desocupações por decisões liminares de reintegração de posse, inclusive com sentença de mérito fundamentada na tese do marco temporal (Idem).

\footnotetext{
${ }^{5}$ As referências às decisões consultadas neste trabalho utilizam os números das páginas dos processos originais, exceto quando as versões disponíveis na internet não forem numeradas, quando será utilizada a numeração do arquivo em pdf.

${ }^{6}$ Áreas inundáveis ao longo do leito do Rio São Francisco que, nos períodos de vazante, deixam terras férteis às margens e nas ilhas que se formam ao longo do rio, muito propícias à agricultura e utilizadas tradicionalmente pelas comunidades tradicionais das beiras do São Francisco.
} 


\section{A INAPLICABILIDADE DO MARCO TEMPORAL QUILOMBOLA E AS RETOMADAS DE TERRAS SOB A PERSPECTIVA DO DIREITO COMO \\ EFETIVIDADE}

Casos como este, ilustram o uso estratégico da tese do marco temporal em socorro aos ocupantes ilegais dos territórios quilombolas, reforçando juridicamente a criminalização das ações de reocupação de suas terras por meio das retomadas, afastando o reconhecimento da posse tradicional pelo Judiciário, enquanto a destruição da política pública de titulação dos territórios consegue frear o reconhecimento do constitucionalizado direito coletivo à terra enquanto direito como efetividade.

\section{O marco temporal no Judiciário e sua inconstitucional aplicação nas ações judiciais contra comunidades quilombolas ou o direito como efetividade ao contrário}

A discussão em torno de uma tese do marco temporal, no Judiciário, ganhou fôlego com a Ação Popular, proposta por ilegais ocupantes da TI Raposa/Serra do Sol, com o objetivo de declarar a nulidade da Portaria n. 820/1998 do Ministério da Justiça que delimitou e demarcou a posse permanente das etnias Ingarikó, Makuxi, Taurepang, Wapixana e Patamona, e anular o Decreto Presidencial de 15/04/2005, que "Homologa a demarcação administrativa da Terra Indígena Raposa Serra do Sol, localizada nos Municípios de Normandia, Pacaraima e Uiramutã, no Estado de Roraima” (BRASIL, 2009).

Julgada parcialmente procedente, a partir do voto do Relator Ministro Carlos Ayres Britto, a ação registrada como Petição 3388/2005 (Idem) fixou importante paradigma jurídico quanto aos direitos originários dos povos indígenas, mas impôs uma série de limitações ao seu pleno exercício, por meio de 19 condicionantes introduzidas pelo Ministro Menezes Direito. Além de garantir status de jurisprudência da mais alta corte do País à tese do marco temporal, influenciando, de forma negativa, propostas legislativas, as políticas fundiárias e a posição do Judiciário sobre os direitos dos povos indígenas e de outros povos e comunidades tradicionais.

O ministro relator admite, com objetivo declarado de "colocar uma pá de cal nas intermináveis discussões sobre qualquer outra referência temporal de ocupação de área indígena [que] a data de verificação do fato em si da ocupação fundiária é o dia 5 de outubro de 1988, e nenhum outro" (BRASIL, 2009, p. 295-296, destaque do autor), estabelecendo como exceção apenas a ocorrência de esbulho renitente, no sentido de que a "tradicionalidade da posse nativa, no entanto, não se perde onde, ao tempo da promulgação da Lei Maior de 1988, a reocupação apenas não ocorreu por efeito de renitente esbulho por parte de não-índios" (Idem, p. 235-236).

Em seu parecer sobre o marco temporal, o constitucionalista José Afonso da Silva considera questionável sua imposição, "porque fixado pretorianamente de modo arbitrário Rev. de Direito Agrário e Agroambiental| e-ISSN: 2526-0081| Evento Virtual| v. 6 | n. 1 | p. 57-77 | Jan/Jun. 2020 
como sendo a data da promulgação da Constituição Federal de 5 de outubro de 1988" (SILVA, 2016, p. 7), ao tempo que pergunta: “Onde está isso na Constituição? Como pode ela ter trabalhado com essa data, se ela nada diz a esse respeito nem explícita nem implicitamente?" (Idem, p. 8).

Mesma crítica procede quanto ao art. 68 do Ato das Disposições Constitucionais Transitórias (ADCT) da Constituição de 1988, que estabelece a obrigação do Estado brasileiro quanto à titulação dos territórios tradicionais quilombolas (BRASIL, 2020), embora não se discuta o reflexo do julgamento da Petição 3388/2005 na ADI 3239/2004 e sua influência para a constante pressão pela aplicação da tese do marco temporal nos procedimentos demarcatórios indígenas e quilombolas.

Na primeira sessão de julgamento da ADI 3239, em 18 de abril de 2012, o voto do Relator, Ministro Cezar Peluso, pela inconstitucionalidade do Decreto $n^{\mathbf{o}} 4.887 / 2003$, reconhecia a aplicação do marco temporal às comunidades quilombolas, tidas como aquelas que "subsistiam nos locais tradicionalmente conhecidos como quilombos [...] antes ou logo após a abolição [...] e lá permaneceram até a promulgação da Constituição de 1988" (BRASIL, 2018, p. 3493).

Com a suspensão do julgamento, por pedido de vista da Ministra Rosa Weber, uma possível reviravolta deste entendimento parece surgir do julgamento dos Embargos Declaratórios na Petição 3388. Em outubro de 2013, sob a relatoria do Ministro Luís Roberto Barroso, foi decidido que as condicionantes da TI Raposa/Serra do Sol não são vinculantes para outras terras indígenas, já que a "decisão proferida em ação popular é desprovida de força vinculante, em sentido técnico, [de forma que] os fundamentos adotados pela Corte não se estendem, de forma automática, a outros processos em que se discuta matéria similar" (BRASIL, 2013, p. 2).

Mas, em setembro de 2014, o Ministro Ricardo Lewandowski foi voto vencido na Segunda Turma do STF, em sua posição contrária à aplicação da tese do marco temporal, a partir de divergência aberta pelo Ministro Gilmar Mendes, seguido pela Ministra Cármen Lúcia e o Ministro Celso de Mello, em julgamento que declarou a nulidade da demarcação da TI Guyraroká, do Povo Guarani e Guarani Kaiowá, no Mato Grosso do Sul (BRASIL, 2014a).

A decisão do STF reafirmou o equívoco de se estabelecer a data de 5 de outubro de 1988 como marco para a verificação da ocupação fundiária por etnia indígena, além de desconsiderar os estudos que revelavam que "os Kaiowá só deixaram a terra devido às pressões que receberam dos colonizadores que conseguiram os primeiros títulos de terras na região" (Idem, p. 13), 


\section{A INAPLICABILIDADE DO MARCO TEMPORAL QUILOMBOLA E AS RETOMADAS DE TERRAS SOB A PERSPECTIVA DO DIREITO COMO \\ EFETIVIDADE}

afastando a ocorrência de esbulho renitente enquanto hipótese de exceção à aplicação do marco temporal.

Já, em dezembro de 2014, a Segunda Turma do STF proferiu novo julgamento, dessa vez sob a relatoria do Ministro Teori Zavascki, seguido por Gilmar Mendes e Cármen Lúcia para, em votação unânime, destituir a posse permanente do Povo Terena sobre a Terra Indígena Limão Verde, também no Mato Grosso do Sul. Sob a alegação de que só configura o renitente esbulho o conflito pela posse que "mesmo iniciado no passado, ainda persista até o marco demarcatório temporal atual (vale dizer, a data da promulgação da Constituição de 1988), conflito que se materializa por circunstâncias de fato ou, pelo menos, por uma controvérsia possessória judicializada" (BRASIL, 2014b, p. 11).

José Afonso da Silva (2016) destaca o tratamento civilista dado à posse indígena no caso, na medida em que se estende no tempo o conceito jurídico de esbulho, mediante o uso da qualificadora "renitente", exigindo-se, daquele que foi lesado, sustentar um conflito "de fato" até a data da promulgação da Constituição de 1988, legitimando a violência como meio de prova do que geralmente já se encontra amplamente demonstrado nos estudos antropológicos que embasam as demarcações e titulações de territórios tradicionais.

Os acórdãos proferidos pela Segunda Turma do STF obrigariam indígenas - e quilombolas, se adotado como paradigma na ADI 3239 - cujos direitos territoriais são originária e historicamente reconhecidos na Constituição, a comprovar uma "posse velha", na forma da lei civil, sob pena de prevalecer a posse violenta e clandestina de terceiros, invasores dos seus territórios (SILVA, 2016).

A exigência de se comprovar o esbulho mediante controvérsia possessória judicializada, em 5 de outubro de 1988, ignora a tutela indigenista ainda em vigor à época, até a Constituição atual admitir, no art. 232, a personalidade jurídica individual e coletiva aos indígenas como "partes legítimas para ingressar em juízo em defesa de seus direitos e interesses" (BRASIL, 2020). Esse é um questionamento que pode também ser feito em relação às comunidades quilombolas, pois não eram reconhecidas enquanto sujeito de direito individual ou coletivamente, antes da promulgação da atual Constituição.

Decerto que os julgados da Segunda Turma do STF influenciaram decisões de primeira instância contrárias às comunidades quilombolas em luta pela reocupação das áreas de seus territórios sob a posse de terceiros, tomando como exemplo a sentença proferida pela Justiça Federal, em Guanambi, Bahia, que deferiu a reintegração de posse contra a comunidade 
quilombola de Barra do Parateca. Nesse caso, a retomada, pela comunidade, de áreas da União apropriadas por fazendas nas margens do Rio São Francisco foi caracterizada como "esbulho" pelo juiz, argumentando que "a aferição da ancestralidade/tradicionalidade quilombola invocada deve ser a data da promulgação da CF de 1988" (BAHIA, 2015, p. 11).

Proferida em setembro de 2015, a sentença também admite a expulsão de quilombolas dessas áreas por fazendeiros na década de 1970, desde quando se emitiram títulos de propriedade particular sobre suas terras. Alega, contudo, com citações diretas do acórdão da Petição 3388 e remissão à reinterpretação do Ministro Teori Zavascki quanto ao esbulho renitente, que "se a expulsão da área pelos não quilombolas se deu muitos anos antes de entrar em vigor a $\mathrm{CF} / 88$, não restará configurado o renitente esbulho, assim como se o conflito tiver cessado ou sofrido lapsos de continuidade neste período" (Idem, p. 11).

Decisões como esta, ainda encontravam guarida, à época, nas interpretações adotadas pela Segunda Turma do STF, já que a Ministra Rosa Weber, em 25 de março de 2015, dando continuidade ao julgamento da ADI 3239, embora apresentasse voto pela improcedência da ação, confirmava o marco temporal de 1988 como requisito essencial da aplicação do art. 68 do ADCT (BRASIL, 2018), reforçando na Suprema Corte a criminalização das ações de retomada de terras protagonizadas pelas comunidades quilombolas.

\section{Os votos favoráveis ao marco temporal quilombola na ADI 3239}

O Ministro Cezar Peluso, em abril de 2012, já havia reconhecido a inconstitucionalidade formal e material do Decreto $\mathrm{n}^{\circ} 4.887 / 2003$, pela suposta ofensa aos princípios da legalidade e da reserva de lei, e por rechaçar os dispositivos que versam sobre a autoatribuição identitária e definição dos critérios de territorialidade pelas comunidades quilombolas. Afirmava ainda a criação de nova espécie de usucapião constitucional por decreto, embora tenha optado pela modulação dos efeitos da decisão, para considerar válidos os títulos de propriedade até então emitidos (BRASIL, 2018).

Além de adotar a definição reducionista da superada acepção histórica de quilombo, considerou que as terras a serem tituladas seriam aquelas cuja posse é secular, entendendo que, segundo o art. 68 do ADCT, seria "reconhecida aos remanescentes das comunidades de quilombolas a posse, contínua, prolongada (estejam ocupando), centenária (que remanescem), exercida com ânimo de dono (suas terras) e qualificada (existente em 05 de outubro de 1988)" (BRASIL, 2018, p. 3496, destaques do autor). 


\section{A INAPLICABILIDADE DO MARCO TEMPORAL QUILOMBOLA E AS RETOMADAS DE TERRAS SOB A PERSPECTIVA DO DIREITO COMO \\ EFETIVIDADE}

O voto divergente da Ministra Rosa Weber (BRASIL, 2018), pela improcedência da ADI 3239, reafirma a natureza do art. 68 do ADCT enquanto norma definidora de direito fundamental de grupo étnico-racial minoritário e, portanto, dotada de eficácia plena e aplicação imediata, sendo desnecessária integração legislativa para assegurar o direito subjetivo nela contido. Reconhece, ainda, a incidência do princípio da proibição do retrocesso social, conforme a jurisprudência do STF de que "a norma constitucional definidora de direito fundamental [...] fixa limite à atuação legislativa, de tal modo que nenhuma lei que venha a ser editada poderá frustrar ou restringir o exercício dos direitos nela - norma constitucional afirmados" (Idem, p. 3543).

Contudo, a Ministra logo se contradiz no item “4.4.4” do voto original, proferido em 25 de março de 2015, entendendo que a "efetiva posse das terras em 05 de outubro de 1988 é requisito essencial à proteção do art. 68 do ADCT, porquanto consta expressamente do tex to constitucional quando identifica seus destinatários" (BRASIL, 2015, p. 44, destaque da autora) 7.

A Ministra Rosa Weber discordou do Relator Cezar Peluso, ao sustentar que a data de 13 de maio de 1888 não tem serventia à definição do status atual dos quilombos. Porém, mesmo sem a restrição aos direitos territoriais quilombolas com referência ao passado histórico, insiste no erro de impor limite à sua existência futura, ao vincular à data de 5 de outubro de 1988 a relação de pertencimento específico das comunidades às suas terras tradicionais (BRASIL, 2015).

Nem mesmo a menção à “óbvia ressalva de hipóteses de eventual prejuízo ou suspensão do efetivo exercício da posse nessa data em razão de turbação ou esbulho" (Idem, p. 44) é capaz de elidir o equívoco da aplicação do marco temporal, por si só, incompatível com o caráter reparatório da opressão histórica e atual sofrida pelo povo negro, contido nos dispositivos da Constituição de 1988 que protegem a identidade, cultura e territorialidade quilombola. A Ministra, assim, renega o princípio da máxima efetividade das normas de direitos fundamentais citado em seu próprio voto, da mesma forma que o Ministro Dias Toffoli, ao retomar o julgamento, em 09 de novembro de 2017, ambos concordando que a:

"posição topográfica" do art. 68 do ADCT não lhe atribuiria "a mesma extensão
normativa dos princípios constitucionais consagrados no texto definitivo da
Constituição, por se tratar de comando transitório e excepcional destinado a

\footnotetext{
${ }^{7} \mathrm{O}$ extrato se refere ao voto originalmente proferido pela Ministra Rosa Weber, em 25/03/2015, que seria alterado quando da lavratura do acórdão pela mesma, após o julgamento definitivo da ADI 3239, em 08/02/2018.
}

Rev. de Direito Agrário e Agroambiental| e-ISSN: 2526-0081| Evento Virtual| v. 6 | n. 1 | p. 57-77 | Jan/Jun. 2020 
solucionar situação verificada ao tempo da promulgação da Carta” (BRASIL, 2018, p. 3606).

Concordam, assim, Rosa Weber e Dias Toffoli, em estabelecer um limite ao art. 68 do ADCT não previsto em seu texto, que afetaria diretamente as comunidades quilombolas em processo de retomada das terras excluídas de sua posse ancestral por terceiros, minando a possibilidade de dar efetividade ao direito territorial, a partir de um entendimento que isolaria a tradicionalidade da posse dos direitos fundamentais que lhe são correlatos.

Em seu voto pela parcial procedência da ADI 3239, Dias Toffoli conferiu interpretação conforme ao $\S 2^{\circ}$, do art. $2^{\circ}$, do Decreto $n^{\circ} 4.887 / 2003$, que trata do critério de autodefinição das comunidades, sob o argumento que "somente devem ser titularizadas as áreas que estavam ocupadas por remanescentes das comunidades dos quilombos, inclusive as utilizadas para a garantia de sua reprodução física, social, econômica e cultural, na data da promulgação da Constituição (5 de outubro de 1988)" (BRASIL, 2018, p. 3620-3621).

Embora concorde o Ministro Dias Toffoli com a Ministra Weber que o conceito colonial de quilombo é insuficiente para a identificação das comunidades amparadas pelo art. 68 do ADCT, afirma que “a locução verbal 'estejam ocupando suas terras', contida no texto constitucional, acaba por delimitar o aspecto temporal do direito, reconhecendo uma ocupação presente, não passada, e [...] nem futura" (Idem, p. 3605-3606, destaque do autor).

Cabe a crítica, analisando o teor do art. 68 do ADCT, de que a expressão "que estejam ocupando" refere-se à identificação dos sujeitos de direito, quais sejam os "remanescentes das comunidades de quilombos". O dispositivo elege, dentre os remanescentes de quilombos que serão titulares do direito territorial ali previsto, aqueles "que estejam ocupando suas terras".

Assim, trata-los como meros "remanescentes das comunidades dos quilombos" enfraquece a importância do reconhecimento constitucional principal que é o da existência histórica dos próprios quilombos (ver Constituição, art. 216, $\$ 5^{\circ}$ ). O lugar (quilombo) e a pessoa (quilombola) se fundem em um conceito que se completa, longe de dizer que alguém que não estivesse no quilombo, no momento da promulgação da atual Constituição, tenha perdido aquela identidade e, por consequência, tenha deixado de ser sujeito de direito ao território ao qual pertence - ainda mais no caso em que esse alguém tenha sido retirado do território quilombola à força, contra sua vontade.

A expressão "que estejam ocupando", diferente de opor um marco temporal que limita sua existência futura, ao impedir o regresso às suas terras tradicionais invadidas por terceiros, 


\section{A INAPLICABILIDADE DO MARCO TEMPORAL QUILOMBOLA E AS RETOMADAS DE TERRAS SOB A PERSPECTIVA DO DIREITO COMO \\ EFETIVIDADE}

apenas diferencia os sujeitos de direito atuais das comunidades que por razões históricas se desintegraram ou foram exterminadas, como o icônico Quilombo dos Palmares.

As retomadas de terras, garantia do direito pela efetividade do exercício da posse, pressupõem a tradicionalidade da sua ocupação, considerando áreas fundamentais à sua sobrevivência física e cultural nos territórios, também aquelas de uso menos constante, mas que guardam relação intrínseca com funções histórico-sociais, como a convivência, o lazer, a religiosidade, ou funções econômicas, como o extrativismo, a caça e a pesca, desenvolvidos sazonalmente.

São justamente tais áreas, onde a ocupação tradicional se dá de forma mais intermitente, que ao longo do tempo foram alvo de apropriação ilegal por terceiros e somente após o advento da proteção legal à posse e propriedade quilombola vêm sendo reocupadas nas ações de retomadas. A interpretação do art. 68 do ADCT como limite temporal ao alcance do Decreto $\mathrm{n}^{\circ}$ 4.887/2003 defendida nos votos então proferidos no julgamento da ADI 3239 trouxe o grave risco de titulação apenas das áreas ocupadas diretamente para a moradia e o plantio voltado à própria alimentação.

O Ministro Gilmar Mendes, já na sessão seguinte, manteve sua posição externada nas ações envolvendo direitos indígenas julgadas pela Segunda Turma do STF, acompanhando integralmente o voto de Dias Toffoli pela interpretação conforme a tese do marco temporal.

\section{A superação do marco temporal e do esbulho renitente na ADI 3239}

Na sessão do julgamento, de 08 de fevereiro de 2018, após ter vista dos autos, o Ministro Edson Fachin proferiu voto pela total improcedência da ação, não acolhendo a interpretação conforme a Constituição defendida por Dias Toffoli e rejeitando a tese do marco temporal da ocupação e o esbulho renitente, na forma admitida por Peluso e Weber.

O Ministro Fachin reconheceu que o elemento definidor da identidade quilombola é a relação tradicional da comunidade com a terra, a "ideia de resistência, de uma comunidade que, ao longo dos anos, apesar da invisibilidade e das dificuldades em relação ao meio, sobrevive e mantém suas tradições” (BRASIL, 2018, p. 3652). Citando obras de expoentes no estudo da questão quilombola para concordar que pode uma comunidade "temporariamente se distanciar de suas terras originárias, mas não perdem sua identidade étnica, que está intrinsecamente ligada à terra, que originou a concepção de povo e que originou a própria comunidade" (SILVA; SOUZA FILHO, 2016, p. 79 - citação transcrita em seu voto: BRASIL, 2018, p. 3653). 
Afasta a premissa de que a autoidentificação deva vir acompanhada da presença da comunidade na área, na data de 05 de outubro de 1988, para impor a terceiros ocupantes o ônus da prova de ausência de ocupação tradicional quilombola, como de fato estabelece o procedimento previsto no Decreto $n^{\circ}$ 4.887/2003. Já que, o fato de ainda não haver o reconhecimento da propriedade quilombola antes da Constituição de 1988 "transforma a prova dessa presença contínua e sem turbação na área na data da promulgação da Constituição bastante difícil, senão impossível a essas comunidades” (BRASIL, 2018, p. 3653).

Também, quanto à posição do art. 68 no ADCT da Constituição, recorda que o próprio STF estabeleceu paridade entre as normas das disposições transitórias e demais normas constitucionais, sobretudo, tratando-se de normas garantidoras de direitos fundamentais, cuja máxima eficácia deve ser garantida. Ao mesmo tempo, conclui pela incoerência de uma hermenêutica da locução verbal, "que estejam ocupando", no mesmo artigo, que atribua proteção apenas às comunidades que consigam comprovar efetiva ocupação, em 5 de outubro de 1988, com base no tempo verbal do dispositivo ou sua topologia dentro do texto constitucional (BRASIL, 2018).

Diferente dos ministros Cezar Peluso e Dias Toffoli, que consideraram o direito das comunidades de retornar aos seus territórios como causa de conflitos fundiários, Edson Fachin ponderou que a "existência desses conflitos não pode inviabilizar o reconhecimento do direito assegurado pelo texto constitucional, colocando essas comunidades, uma vez mais, à margem da tutela pelo ordenamento jurídico" (Idem, p. 3658).

O Ministro Roberto Barroso relembrou que a tese do marco temporal teve sentido e alcance limitado ao julgamento do caso Raposa/Serra do Sol, conforme decisão proferida nos Embargos de Declaração de sua relatoria. Propôs ele que a prova da preservação de vinculação com a área quilombola não deva se dar por meio de conflitos ou ações possessórias, como propunha o Ministro Teori Zavascki, porque recorrer ao Poder Judiciário, ou mesmo à violência de conflitos físicos, não seria da índole das comunidades (BRASIL, 2018). Referendar tais condutas, além de atentar contra o próprio instinto de sobrevivência, significa interpretar o comportamento das comunidades à luz dos nossos costumes e instituições, o que não se adequa à preservação da sua cultura enquanto propósito da Constituição (Idem).

Com um indicativo favorável às retomadas de terras, afirma o Ministro Barroso que a propriedade quilombola deve se estender por todo o espaço territorial necessário à preservação de sua cultura e do seu modus vivendi, reconhecendo que fazem jus ao território as comunidades que foram forçosamente desapossadas, "mas cujo comportamento, à luz da sua cultura, aponta 


\section{A INAPLICABILIDADE DO MARCO TEMPORAL QUILOMBOLA E AS RETOMADAS DE TERRAS SOB A PERSPECTIVA DO DIREITO COMO

para sua inequívoca intenção de retornar ao território que ocupavam [e] de retomar a permanência do vínculo cultural e tradicional com o território" (BRASIL, 2018, p. 3663-3664, grifo inexistente no original).

O Ministro Ricardo Lewandowski não fez menção expressa, em seu voto, à tese do marco temporal, pois opinou pelo não conhecimento da ação. Vencido neste ponto, votou pela sua improcedência. Porém, nova intervenção de Dias Toffoli pela aplicação do marco temporal aos quilombos como forma de prevenir futuras ampliações de territórios, o levou a se afirmar contrário ao marco temporal, considerando a comprovação de esbulho renitente, ainda que mediante todo meio de prova juridicamente admitido, uma "prova diabólica", pois "difícil ou impossível de ser produzida", não admitindo uma inversão do ônus da prova, em que um grupo hipossuficiente tenha de assumi-la (Idem, p. 3706-3707).

O Ministro Luiz Fux concordou que a finalidade constitucional de proteção das comunidades quilombolas desautoriza qualquer restrição cronológica de seu alcance, desde que “a interpretação gramatical do texto constitucional não encontra qualquer referência em datas ou outro parâmetro temporal”. Reconhece as retomadas de terras, ao afirmar que a discutida locução verbal "que estejam ocupando", em verdade "demonstra a atualidade e a continuidade da ocupação, incluindo no campo semântico da garantia, por exemplo, aqueles que outrora foram removidos forçosamente de suas terras, mas já presentemente conseguiram reavê-la" (BRASIL, 2018, p. 3754-3755, grifo inexistente no original).

Admite, ainda, o Ministro Fux, que a tese do marco temporal também poderia excluir comunidades que ao tempo da promulgação da Constituição não tivessem consciência de sua identidade ou conhecimento dos seus direitos, "não preenchendo os requisitos socioculturais suficientes, mas, somados os quase trinta anos transcorridos desde então, atualmente já fortaleceu suas raízes" (Idem, p. 3755). Rejeita, portanto, a aplicação acessória do conceito de esbulho renitente, pois:

A transferência às comunidades remanescentes dos quilombolas do ônus de comprovar os atos ilícitos que lhes comprometeram a continuidade da posse perpetua uma situação de opressão racial. [Já que a] histórica discriminação a que foram submetidos, inclusive institucional, bem como a oralidade que caracteriza a transmissão de tradições, conhecimento e informações nas comunidades, onera sobremaneira a produção dessas provas pelos remanescentes dos quilombos" (BRASIL, 2018, p. 3725-3726).

Segundo Fux, se os meios de prova do esbulho já se mostram excessivamente restritivos tendo em vista a constante "belicosidade das questões fundiárias e a dificuldade de as comunidades remanescentes dos quilombolas reagirem jurídica e tempestivamente às lesões 
possessórias, a existência em si de um marco temporal tende a chancelar os efeitos de posses ilegais e muitas vezes violentas" (Idem, p. 3759).

O Ministro Marco Aurélio, em princípio, se posicionou pela inadmissão da ação. Voto vencido, contudo, julgou também improcedente o pedido. Ao passo que o Ministro Celso de Mello acompanhou o voto da Ministra Rosa Weber, julgando improcedente a ação, porém adotando a observação de Edson Fachin quanto à rejeição da tese do marco temporal, concluindo também, na parte dispositiva de seu voto, pela improcedência do pedido ${ }^{8}$.

Fato importante, nas discussões do Plenário após as leituras dos votos, a Ministra Rosa Weber declara haver se manifestado sobre a tese do marco temporal em obiter dictum, ou seja, de passagem, por mera força da retórica, comprometendo-se inclusive a suprimir a referência em seu voto, já que havia se posicionado pela total improcedência da ação.

A ausência de menção à inaplicabilidade do marco temporal quilombola na ementa do acórdão levou ainda à oposição de embargos de declaração (BRASIL, 2019), que não foram conhecidos, pois a jurisprudência do STF não reconhece a legitimidade das organizações que atuaram como amici curiae para opô-los. Ainda assim, os ministros Fachin e Barroso reafirmaram, em seus votos nos embargos, a decisão de não acolhida à tese do marco temporal pelo Plenário.

\section{As retomadas de terras e a disputa pelo Direito como efetividade}

Ao julgar, por maioria absoluta, a total improcedência da ADI 3239/2004, o Plenário do STF manifestou-se contrário à tese do marco temporal, que embora não fosse o objeto central da ação, foi levantada na petição inicial, ao menos enquanto uma das causas de pedir da declaração de inconstitucionalidade material do art. $2^{\circ}$ do Decreto $n^{\circ} 4.887 / 2003$.

Os votos no acórdão da ADI 3239/2004 revelam que a aplicação da tese do marco temporal aos quilombos foi afastada expressamente pelos ministros Fachin, Barroso, Fux, Lewandowski, Celso de Mello e pela Ministra Rosa Weber. Enquanto, ainda que de forma não expressa, o Ministro Marco Aurélio e a Ministra Cármen Lúcia, não adotando a interpretação conforme a Constituição postulada pelos ministros Dias Toffoli e Gilmar Mendes, também se posicionaram contra o seu acolhimento.

\footnotetext{
${ }^{8}$ Embora não tenha juntado a íntegra do seu voto ao acórdão, é possível acessar o vídeo da leitura do voto do Ministro Celso de Mello em Plenário, através da gravação do julgamento, transmitido pela TV Justiça no canal do STF no youtube. Disponível: https://www.youtube.com/watch?v=gaLcOajGV8Y. Acesso em 12 mar. 2020. 


\section{A INAPLICABILIDADE DO MARCO TEMPORAL QUILOMBOLA E AS RETOMADAS DE TERRAS SOB A PERSPECTIVA DO DIREITO COMO \\ EFETIVIDADE}

Ainda assim, passados dois anos do julgamento da ação, não se pode admitir que a histórica decisão do STF trouxe mudanças concretas nas vidas das inúmeras comunidades quilombolas que aguardam, enfrentando todos os problemas decorrentes da inércia estatal, pela efetivação do direito à propriedade de seus territórios tradicionais, principal garantia de liberdade nos seus modos de criar, fazer e viver, conforme o art. 216, II, da Constituição (BRASIL, 2020).

A lei existe. Sob a forma de normas constitucionais e infraconstitucionais, cujo questionamento levou ao julgamento pela constitucionalidade do Decreto $\mathrm{n}^{\circ} 4.887 / 2003$, inclusive sob o fundamento da eficácia plena e aplicabilidade imediata do art. 68 do ADCT da Constituição. Porque, então, a lei não acontece? Porque não se efetiva o Direito textual?

Responder a essas perguntas remete, a princípio, à necessidade de se adotar uma definição de Direito que responda às expectativas criadas para as comunidades quilombolas pela Constituição e pela legislação em vigor. Assim, para efeito da discussão aqui proposta, tomando o sentido de liberdade que a conquista do território significa para as comunidades, partimos da proposta de Roberto Lyra Filho (1982), criador da expressão "Direito Achado na Rua”, quando discorre sobre o entrelaçamento entre Justiça e Direito e a frequente dissociação entre Direito e lei.

Para Lyra Filho, lei não se confunde com o Direito, enquanto Justiça e Direito só podem caminhar enlaçados quando dessa união faz surgir Justiça Social. Assim, a atualização de princípios condutores que emergem das lutas sociais conduzirá "à criação duma sociedade em que cessem a exploração e opressão do homem pelo homem; [em que] o Direito não é mais, nem menos, do que a expressão daqueles princípios supremos, enquanto modelo avançado de legítima organização social da liberdade” (LYRA FILHO, 1982, p. 121).

O Direito é concebido como processo de construção histórico, um "vir-a-ser que se enriquece nos movimentos sociais de libertação das classes e grupos ascendentes e que definha nas explorações e opressões que contradizem, mas de cujas próprias contradições brotarão novas conquistas" (Idem). Concepção que se aproxima da tese que postula a efetividade como "critério de identificação e reconhecimento de existência do direito" (SIQUEIRA, 2016, p. 128).

A proposta de explicação e de afirmação do Direito como efetividade, na medida em que sustenta como requisito para a existência do direito a sua efetivação no mundo concreto, 
faz exatamente a ligação concebida por Lyra Filho entre o direito e o engajamento que emerge das lutas sociais em busca da realização de direitos fundamentais à existência humana.

Portanto, a lei não se identifica com o Direito, desde que este não se efetiva apenas a partir das atuações de legisladores, tampouco enquanto também não assume efetividade pela ação de administradores ou pela decisão de magistrados. O que existe, até então, é uma promessa de direito, ou um direito em expectativa, até que, no caso, pelo cumprimento da lei, na sua concretização, venha a ser Direito como efetividade.

O fato de estar previsto na Constituição, em normas infraconstitucionais e mesmo em tratados internacionais de direitos humanos não tem garantido a efetivação da titulação dos territórios tradicionais quilombolas enquanto direito - ou seja, prevalece a negação do direito textual numa espécie de Direito como efetividade ao contrário. Isto porque, na prática, por diversas maneiras, a lei formal vem sendo utilizada para negar o direito material.

Exemplos disso podem ser encontrados, no presente caso: com a própria edição do revogado Decreto $n^{\mathbf{0}} 3912 / 2001$, que apenas reconhecia a propriedade quilombola sob uma absurda modalidade de usucapião de cem anos, como bem alerta o Ministro Roberto Barroso em seu voto acima citado (BRASIL, 2018); tanto mais, pelo congelamento da política fundiária em proveito de interesses políticos e econômicos, que correspondem entre si dentro e fora do Estado. São casos típicos do uso do direito para negar o Direito, seja por meio da sua positivação, seja por meio da sua (não) aplicação pela administração.

O mesmo ocorre nas disputas processuais no Judiciário, como se tentou com o próprio ajuizamento da ADI 3239/2004 no STF pelo então Partido da Frente Liberal (PFL), atual Partido Democratas (DEM), bem como com a proposição de ações possessórias nas instâncias inferiores (e decisões nelas proferidas) com fundamento na tese do marco temporal.

É neste ponto, sobretudo quando o próprio Estado se torna instrumento de negação do direito, que o Direito como efetividade se fundamenta e dialoga com as ações de retomadas ou reocupações das terras e territórios tradicionais. A lei poderá, certamente, ser um dos caminhos para se chegar a um direito. Mas mesmo a norma constitucionalmente inscrita, nunca será direito, de fato, se não se realiza como efetividade.

A não existência de condições para a produção de efeitos de uma norma, ou sua negação mesmo diante das mobilizações de seus interessados mais diretos significa um grau ainda maior de inexistência de direito. A concepção de um direito dinâmico, fruto de um processo histórico de construção, de mobilizações e lutas humanas, de criação permanente, não coincide com a ideia de norma genérica, abstrata ou mesmo difusa, assim, só encontrará sua existência nas 
conquistas alcançadas nos processos de mobilizações sociais, o que lhe conferirá efetividade (SIQUEIRA, 2016).

Se aqui considerarmos o Estado, como instituição organizada pela associação política de cidadãos, lugar aonde se cria direito na forma da lei, é necessário reconhecer esta preexistência do direito apenas na forma sugerida de um direito-promessa, como um momento em que se abrem oportunidades e caminhos, inclusive para refutações, recusas e resistências, resultante das lutas travadas para sua criação, seja como efetividade da lei, para além da lei e até mesmo diante da ausência da lei (Idem).

$\mathrm{O}$ direito à propriedade quilombola previsto no art. 68 do ADCT, embora admitido pelo STF como norma definidora de direitos fundamentais cuja aplicação deveria ser imediata, percorreu um largo caminho de enfrentamento à oposição de seus adversários, sempre submetido a longos e tortuosos processos de interpretação. Raramente, contudo, encontrando efetividade, enquanto satisfação pela via administrativa ou judicial, mesmo passados mais de trinta anos do compromisso político-jurídico na Constituição de 1988.

Portanto, as ações de retomadas ou reocupações dos territórios quilombolas devem ser compreendidas, à luz da decisão que reconheceu a constitucionalidade do Decreto $\mathrm{n}^{\mathrm{o}}$ 4.887/2003 e a não aplicação da tese do marco temporal aos procedimentos que dão concretude ao direito-promessa previsto no art. 68 do ADCT, como forma legal e legítima de leva-lo à efetividade.

\section{Considerações finais}

Não é de agora que tribunais superiores reconhecem que ocupar terras para fins de reforma agrária configura um direito coletivo, expressão da cidadania, que visa a implantar programa constante da Constituição da República, admitindo o direito de pressão popular como garantia própria do Estado de Direito democrático e, consequentemente, afastando a incidência da Lei Penal, como decidiu o Superior Tribunal de Justiça (BRASIL, 1997).

As retomadas de terras são também uma expressão de como o ideal de justiça social busca alcançar a efetividade jurídica, aplicando o direito de fora para dentro das instituições do Estado, através de uma luta que rompe com a sacralização da propriedade em função de uma visão de mercado, para afirmar uma funcionalidade voltada para a terra enquanto mantenedora de vida e diversidades. 
A possibilidade de concretização do direito previsto no art. 68 do ADCT como efetividade vem mobilizando, por décadas, a luta das comunidades para recuperar a posse de suas terras ancestrais. Do outro lado, os interesses contrários à sua efetivação e suas representações políticas promovem o imobilismo dos órgãos executivos, propostas de retrocessos legislativos, ou mesmo sofisticadas interpretações conservadoras e mesmo retrógradas de direitos conquistados com muitos custos, como atestam as tentativas de imposição de um marco temporal aos direitos coletivos aos territórios tradicionais.

Em outro sentido - realizador de direito -, concluímos que o julgamento da ADI 3239/2004 desobstrui o caminho da Constituição e da lei, para que as comunidades quilombolas continuem a reivindicar o direito à inteireza dos seus territórios, mediante o uso estratégico das ações de retomada ou reocupação das áreas invadidas ilegalmente por terceiros, como forma de garantir o Direito previsto no art. 68 do ADCT como efetividade.

\section{REFERÊNCIAS}

ALARCON, Daniela Fernandes. O retorno da terra: as retomadas na aldeia tupinambá da Serra do Padeiro, Sul da Bahia. São Paulo: Elefante, 2019.

BAHIA. Justiça Federal. Subseção Judicária de Guanambi. Reintegração de Posse. 95552.2008.4.01.3309. Autor: Dagmar Pedro Silva. Réu: Associação Agro-Pastoril Quilombola de Barra do Parateca e outros. Juiz: Diogo Souza Santa Cecília. 01 de setembro de 2015. In: Diário da Justiça Federal da 1 ${ }^{\text {a }}$ Região/BA. 8 out. 2015. p. 482.

BRASIL. [Constituição Federal (1988)]. Constituição da República Federativa do Brasil. Brasília: Senado Federal, 1988. In: Diário Oficial da República Federativa do Brasil, Brasília, DF, Presidência da República, [2020]. Disponível em: http://www.planalto.gov.br/ccivil_03/constituicao/constituicao.htm. Acesso em: 10 mar. 2020.

. Decreto $\mathrm{n}^{\circ} 3.912$, de 10 de setembro de 2001. Regulamenta as disposições relativas ao processo administrativo para identificação dos remanescentes das comunidades dos quilombos e para o reconhecimento, a delimitação, a demarcação, a titulação e o registro imobiliário das terras por eles ocupadas. In: Diário Oficial da República Federativa do Brasil, Brasília, DF, 10 set. 2001.

Decreto $\mathrm{n}^{\circ} 4.887$, de 20 de novembro de 2003. Regulamenta o procedimento para identificação, reconhecimento, delimitação, demarcação e titulação das terras ocupadas por remanescentes das comunidades dos quilombos de que trata o art. 68 do Ato das Disposições Constitucionais Transitórias. In: Diário Oficial da República Federativa do Brasil, Brasília, DF, 21 nov. 2003.

. Decreto $n^{\circ} 5.051$, de 19 de abril de 2004. Promulga a Convenção no 169 da Organização Internacional do Trabalho - OIT sobre Povos Indígenas e Tribais. In: Diário Oficial da República Federativa do Brasil, Brasília, DF, 24 abr. 2004. 


\section{A INAPLICABILIDADE DO MARCO TEMPORAL QUILOMBOLA E AS RETOMADAS DE TERRAS SOB A PERSPECTIVA DO DIREITO COMO \\ EFETIVIDADE}

. Decreto $\mathrm{n}^{\mathrm{o}}$ 6.040, de 7 de fevereiro de 2007. Institui a Política Nacional de Desenvolvimento Sustentável dos Povos e Comunidades Tradicionais. In: Diário Oficial da República Federativa do Brasil, Brasília, DF, 8 fev. 2007.

Superior Tribunal de Justiça (6. Turma). Habeas Corpus 5574/SP. Impetrado: Desembargador Segundo Vice Presidente do Tribunal de Justiça do Estado de São Paulo. Pacientes: Marcio Barreto e outros. Relator: Ministro William Patterson. Relator p/ acórdão: Ministro Luiz Vicente Cernicchiaro, 08 de abril de 1997. Disponível em: https://ww2.stj.jus.br/processo/ita/listarAcordaos?classe=\&num_processo=\&num_registro=19 9700102360\&dt_publicacao=18/08/1997. Acesso em: 16 mar. 2020.

. Supremo Tribunal Federal (Tribunal Pleno). Petição 3388 RR - Roraima. Petição. Requerente: Augusto Affonso Botelho Neto. Requerido: União. Relator: Min. Carlos Ayres Britto, 19 de março de 2009. Disponível em: http://redir.stf.jus.br/paginadorpub/paginador.jsp?docTP=AC\&docID=630133. Acesso em: 11 mar. 2020.

Supremo Tribunal Federal (Tribunal Pleno). Petição 3388 ED/RR - Roraima. Embargos de Declaração na Petição. Embargante: Augusto Affonso Botelho Neto e outros. Embargado: União. Relator: Min. Roberto Barroso, 23 de outubro de 2013. Disponível em: http://redir.stf.jus.br/paginadorpub/paginador.jsp?docTP=TP\&docID=5214423. Acesso em: 11 mar. 2020.

Supremo Tribunal Federal (2. Turma). Recurso em Mandado de Segurança 29087/DF

- Distrito Federal. Recorrente: Avelino Antonio Donatti. Recorrido: União. Relator: Min. Ricardo Lewandowski. Relator p/ Acórdão: Min. Gilmar Mendes, 16 de setembro de 2014a. Disponível

em: http://redir.stf.jus.br/paginadorpub/paginador.jsp?docTP=TP\&docID=6937880. Acesso em: 11 mar. 2020.

Supremo Tribunal Federal (2. Turma). Agravo Regimental 803462 AgR/MS - Mato Grosso do Sul. Agravante: Tales Oscar Castelo Branco. Agravado: União. Relator: Min. Teori Zavascki, 9 de dezembro de 2014b. Disponível em: http://redir.stf.jus.br/paginadorpub/paginador.jsp?docTP=TP\&docID=7734834. Acesso em: 11 mar. 2020.

Supremo Tribunal Federal (Tribunal Pleno). Ação Direta de Inconstitucionalidade 3239/DF - Distrito Federal. Requerente: Democratas. Requerido: Presidente da República. Voto: Min. Rosa Weber, 25 de março de 2015. Disponível em: http://www.stf.jus.br/portal/cms/verNoticiaDetalhe.asp?idConteudo=288349. Acesso em: 11 mar. 2020.

Supremo Tribunal Federal (Tribunal Pleno). Ação Direta de Inconstitucionalidade 3239/DF - Distrito Federal. Requerente: Democratas. Requerido: Presidente da República. Relator: Min. Cezar Peluso. Relatora p/ acórdão: Min. Rosa Weber, 8 de fevereiro de 2018. Disponível

em: 
http://portal.stf.jus.br/processos/downloadPeca.asp?id=15339396721\&ext=.pdf. Acesso em: 11 mar. 2020.

. Supremo Tribunal Federal (Tribunal Pleno). Embargos de Declaração na Ação Direta de Inconstitucionalidade 3239/DF - Distrito Federal. Embargantes: Associação dos Quilombos Unidos do Barro Preto e Indaiá e outros Embargado: Democratas. Relatora: Min. Rosa Weber, 13 de dezembro de 2019. Disponível em: http://portal.stf.jus.br/processos/downloadPeca.asp?id=15342622889\&ext=.pdf. Acesso em: 15 mar. 2020.

CHAVES, Carlos E. L.; CORREIA, Maurício. Nota técnica: Fundamentos para rejeição da PEC 215/00 - Impactos sobre os povos tradicionais e o bioma cerrado. Rio de Janeiro: ActionAid, 2018. Disponível em: http://actionaid.org.br/wpcontent/files_mf/1524082151215.pdf. Acesso em: 10 mar. 2020.

LYRA FILHO, Roberto. O que é Direito. São Paulo : Editora Brasiliense, 1982.

MONTEIRO, Aianny Naiara Gomes; TRECCANI, Girolamo Domenico. A tese do marco temporal da ocupação quilombola à luz da teoria da integridade de Dworkin: Análise dos votos da ADIN 3239. Revista de Direito Agrário e Agroambiental, Goiânia. v. 5, n. 1, p. 18-39, jan./jun. 2019. Disponível em: https://www.indexlaw.org/index.php/rdaa/article/view/5507. Acesso em: 12 mar. 2020.

SILVA, José Afonso da. Parecer. 2016. Disponível em: http://www.mpf.mp.br/atuacaotematica/ccr6/documentos-e-publicacoes/artigos/docs_artigos/jose-afonso-da-silva-parecermaio-2016-1.pdf. Acesso em: 12 mar. 2020.

SILVA, Liana Amin Lima da; SOUZA FILHO, Carlos Frederico Marés de. Marco temporal como retrocesso dos direitos territoriais originários indígenas e quilombolas. In: WOLKMER, Antonio Carlos; MARÉS DE SOUZA FILHO, Carlos Frederico; TARREGA, Maria Cristina Vidotte Blanco. Os direitos territoriais quilombolas: além do marco temporal. Goiânia: Ed. da PUC-Goiás, 2016.

SIQUEIRA, José do Carmo Alves. Direito como efetividade e luta pela terra no Brasil. Tese (Doutorado em Direito) - Faculdade de Direito, Universidade de Brasília, Brasília/DF, 2016.

SOLAZZI, J. L.; WOLKMER, Antonio Carlos. Interpretação constitucional, pluralismo jurídico e a questão quilombola: uma abordagem descolonial e intercultural do decreto $\mathrm{n}^{\mathbf{o}}$ 4.887/2003 e da ADI 3239. In: WOLKMER, Antonio Carlos; MARÉS DE SOUZA FILHO, Carlos Frederico; TARREGA, Maria Cristina Vidotte Blanco. Os direitos territoriais quilombolas: além do marco temporal. Goiânia: Ed. da PUC-Goiás, 2016. 